American Journal of Pharmaceutical Education 2019; 83 (3) Article 7431.

\title{
COMMENTARY
}

\section{Keeping the School of Pharmacy Connected to the University}

\author{
Timothy J. Bloom, $\mathrm{PhD}^{\mathrm{a}, \mathrm{b}}$ \\ ${ }^{a}$ Bernard J. Dunn School of Pharmacy, Shenandoah University, Winchester, Virginia \\ ${ }^{\mathrm{b}}$ Editorial Board Member, American Journal of Pharmaceutical Education, Arlington, Virginia
}

Submitted November 19, 2018; accepted December 3, 2018; published April 2019.

Keywords: cooperation, collaboration

Aside from a small group of standalone institutions, US colleges and schools of pharmacy are components of a larger university. The Accreditation Council for Pharmacy Education Standards 2016 describe the relationship that exists between a school and its university as a combination of connectedness and independence. Key element 8.1 of the standards states: "University leadership and the college or school dean collaborate to advance the program's vision and mission and to meet ACPE accreditation standards. The dean has direct access to the university administrator(s) with ultimate responsibility for the program." "The standards also require that schools and colleges of pharmacy have a degree of institutional independence. Key element 5.1 states: "The academic unit offering the Doctor of Pharmacy program is an autonomous unit organized as a college or school of pharmacy (within a university or as an independent entity). This includes autonomy to manage the professional program within stated policies and procedures, as well as applicable state and federal regulations." ${ }^{\text {Th }}$ This independence helps protect pharmacy schools from the possibility that an institutional administration might try to address short-term problems with solutions incompatible with our charge to prepare students to be APPE-, team- and practice-ready. The independence does not, however, mean we should stand apart from other schools that are part of our university.

A school of pharmacy should have a strong and dynamic connection to the larger university. Working together with other departments and schools across campus can enhance us as educational providers. This can come through access to more diverse faculty expertise and background. A school of education is likely to have faculty willing and able to develop our understanding of pedagogy and educational research. It is not uncommon for doctoral programs, whether $\mathrm{PhD}$ or PharmD, to have

Corresponding Author: Timothy J. Bloom, Bernard J. Dunn School of Pharmacy, Shenandoah University, 1775 N. Sector Ct., Winchester, VA 22601. Tel: 540-678-4395. E-mail:

tbloom2@su.edu minimal training related to teaching, so help from school of education colleagues could be helpful to many new pharmacy faculty members. Faculty at schools of business may have a much better understanding of entrepreneurship or leadership, topics that can be difficult to incorporate into our curriculum to meet accreditation standards. Biomedical and pharmaceutical science faculty who feel constrained to teach primarily through lecturing because "there's so much content I absolutely must cover" may benefit from speaking with cross-campus colleagues about the growing use of active learning in undergraduate science, engineering, technology and math (STEM) education. ${ }^{2-5}$

Working with other health professions programs on campus can help schools of pharmacy meet interprofessional education requirements, and provide course subject material and collaborative research opportunities. Pharmacy is different from many biomedical professions in that there is a strong base of not just biology but also multiple areas of chemistry. That breadth of background can make it difficult to have a faculty expert in every foundational discipline. Smaller schools of pharmacy may benefit from the anatomy and physiology expertise of faculty in a physician assistant or physical therapy program, for example. It is also possible that a faculty member with an overlapping research interest who might serve as a collaborator or mentor can be found in another department or school. Extramural funding applications are often strengthened by interdisciplinary collaboration, which is another reason to be aware of research going on in other departments or schools at your university.

Dual degree programs are also an example of working with another school, both in health professions and other disciplines such as business. These programs provide a way for students to stand apart when seeking a residency and allow for broadening a student in areas of interest that we cannot cover in the PharmD curriculum. These programs are becoming more popular, as evidenced by increasing numbers of schools of pharmacy offering them, and of student pharmacists participating. 


\section{American Journal of Pharmaceutical Education 2019; 83 (3) Article 7431.}

The logistics of developing and maintaining a dual degree program can be daunting if there is not a collegial relationship with the other program's department or school.

Stronger connections with undergraduate programs on campus can help us understand, and contribute to, the preparation of students we hope to have in our admissions pipeline. Relationships with undergraduate science faculty may help them feel more invested in making their students aware of the PharmD as a potential pathway and may enhance interest in working with pharmacy schools to create so-called three-plus-one programs. These allow the first year of a PharmD program to serve as part of the requirements for a bachelor's degree, letting a student get both degrees in seven years. Although most US pharmacy schools do not require a bachelor's degree for admission, many students and their families consider a bachelor's an important reason for going to college. Saving the costs of a year of undergraduate studies can be a strong motivator for those deciding on when to apply to pharmacy school. In addition, the granting of an undergraduate degree helps maintain student retention and graduation rates for the undergraduate program, a benefit to the department and school the student is leaving for pharmacy school.

There can be multiple offices across campus that work together to promote student success. Strong connections between our school and the rest of the university may make it easier for students to access the services these offices provide. This includes physical and mental health services available from the university, but also academic support. A student in a school that doesn't encourage an affiliation with the larger university may hesitate to reach out for these services early, when they can do the most good. A university is more likely to have a writing center than is a pharmacy school, but do student pharmacists consider it a resource available to them? Likewise, a center for teaching and learning to help support faculty development is more likely to be a campus initiative than a pharmacy school's. Do our faculty recognize that these centers offer pedagogical support that is disciplineindependent? There can be a hesitancy to reach out to others for help and support, but a feeling of connectedness can make overcoming that barrier a little easier.

What promotes the interactions with other schools across a campus that allow for strong connections? It might be formalized in the university governance structure, involving both administrators and faculty. One example found at many universities is a dean's council, an administrative group that allows coordination of the university mission among the various schools and provides campus-wide awareness of work done to forward that mission. Pharmacy faculty contribute to shared governance by working on university-level committees. Important connections also come from pharmacy faculty teaching in other programs, such as teaching pharmacology in other health professions programs, or even to undergraduate students at larger institutions. Research collaborations are potentially the most powerful type of connection considering the passion that many have for their research area and the importance placed on research for promotion and tenure decisions.

Connections to other departments and schools can also start, and be maintained, in more informal settings. Meaningful relationships often start in a social environment. Mingling at a university function with faculty from other schools or sharing a cafeteria table with someone from another school during lunch can lead to conversations that address issues we all face every day. Academics often enjoy griping about two topics - students and administrators - regardless of their discipline. Consider using these easy icebreakers the next time you are trying to get to know colleagues from another school on your campus.

These days, there are many barriers we can build between ourselves and others. It seems that more and more frequently we are dividing ourselves into tribes, each focused on its own survival. Many of the institutions that once held us together in larger groups are losing popularity or have fallen by the wayside. We sometimes forget that there is strength in diversity, cooperation and collaboration. It can be easy to have a separation between different schools in a university, whether simply from being in different buildings, or from literally being on a different campus. Looking beyond our own school takes an effort, and it can be easy to choose to devote the time needed to our many responsibilities. During over 20 years in academic pharmacy, I have consistently tried to develop and maintain working relationships with faculty in other departments and schools at my university. My time chairing a university faculty senate taught me more about the issues facing the university than anything else I had done prior to taking on my current administrative role. Collaborating to get extramural funding led to teaching and research opportunities I would have missed by staying within my own school. Staying a part of the larger university is not always easy, but I would argue that it is definitely worthwhile. It would have been simpler to just stay within my own school, but being a part of a larger community has made me a better faculty member and more satisfied as a teaching professional.

\section{REFERENCES}

1. Accreditation Council for Pharmacy Education. Accreditation standards and key elements for the professional program in pharmacy 


\section{American Journal of Pharmaceutical Education 2019; 83 (3) Article 7431.}

leading to the doctor of pharmacy degree. Standards 2016. https:// www.acpe-accredit.org/pdf/Standards2016FINAL.pdf. Accessed November 19, 2018.

2. Laws P, Sokoloff D, Thornton R. Promoting active learning using the results of physics education research. UniServe Science News. 1999;13:14-19.
3. Prince M. Does active learning work? A review of the research. $J$ Eng Educ. 2004;93:223-231.

4. Michael J. Where's the evidence that active learning works? $A d v$ Physiol Educ. 2006;30(4):159-167.

5. Freeman S, Eddy SL, McDonough M, et al. Active learning boosts performance in STEM courses. PNAS. 2014;111(23):8410-8415. 